Japan. J. Breed. $37: 367 \sim 376$ (1987)

\title{
Synthetic Hexaploids Derived from Wild Species Related to Sweet Potato
}

\author{
Itaru Shiotani and Tsuneo Kawase \\ Faculty of Agriculture, Mie University, Tsu, $\bar{\top} 514$
}

\begin{abstract}
The utilization of germplasm of the wild species in sweet-potato breeding has been conducted for the last three decades. Such attempts brought some remarkable achievments in improving root yield, starch content and resistance to the nematodes of sweet potato. Some wild plants in polyploid series may have many genes potentially important for further improvement of the agronomic traits. However, the genomic relationship between the wild relatives and hexaploid sweet potato $(2 n=6 x=90)$ has been unrevealed. Meiotic studies were carried out on the hexaploids synthesized with diploids and tetraploids and on the $F_{1}$ hybrids, when possible, with sweet potato. Chromosomes in pollen mother cells (PMC's) and root tip cells were fixed in Newcomer's solution and stained according to. Feulgen reaction with Schiff's reagent. The present report was concerned with two kinds of the synthetic hexaploids. The first was the hexaploids derived from chromosome doubling of triploid hybrids between Ipomoea lacunosa (K 61, $2 n=30$ ) and I. tiliacea (K 134, $2 n=60$ ). the synthetic hexaploid exhibited mostly regular meiosis with bivalents at the metaphase I stage (MI), and it was considered an allo- or segmental allo-hexaploid. The synthetic hexaploids were fertile, but failure in obtaining hybrids by crosses with sweet potato suggested a critical reproductive barrier between them. The second synthetic hexaploids with $2 x$ I.trifida (K 221, $2 n=30$ ) and $4 x$ I.trifida (K 233, $2 n=60$ ) showed the chromosome configurations characterized by the occurrence of tetravalents and hexavalents. Such multivalent associations, high in frequency and number per cell, suggested the presence of the genomes at least in quadruplicate. Similar pattern of the chromosome configurations was observed in a cultivar of sweet potato and the $F_{1}$ hybrid between the synthetic hexaploid and sweet potato. Consequently, the genomic formula for sweet potato was proposed as $\mathrm{B}_{1} \mathrm{~B}_{1} \mathrm{~B}_{2} \mathrm{~B}_{2} \mathrm{~B}_{2} \mathrm{~B}_{2}$, in which $\mathrm{B}_{1} \mathrm{~B}_{1}$ was given to $2 x$ I.trifida and $\mathrm{B}_{2} \mathrm{~B}_{2} \mathrm{~B}_{2} \mathrm{~B}_{2}$ to $4 x$ I.trifida. However, it is necessary to clarify the degree of homology between $B_{1}$ and $B_{2}$ genomes for more conclusive genomic constitution of sweet potato. A brief account was given for the taxonomic identification of the wild Ipomoea strains used in the present study.
\end{abstract}

KEY WORDS : Ipomoea batatas, sweet potato, interspecific hybrid, synthetic hexaploid, genome analysis

\section{Introduction}

Utilization of wild germplasm in sweet-potato breeding began in 1956 immediately after an introduction of the wild hexaploid plants $(2 n=90)$, designated $\mathrm{K} 123$, by Nishiyama from Mexico (Nishiyama and Teramura 1962 ; Nishiyama 1963, 1971). Subsequently, K 123-derived lines have attracted much attention mainly because of their high starch yield and resistance to two major nematodes. Breeding methods and achievments with improved cultivars were briefly reviewed by KoBAYASHI (1978).

Besides K 123, many wild plants related to sweet potato have been introduced from Mexico, Guatemala, Colombia, Ecuador and the United States, and they formed a series of diploids, triploids, tetraploids and hexaploids. Therefore, there is a possibility that genomes of the wild plants at the diploid and tetraploid levels are constituents of the genomic structure of sweet potato.

Received January 5, 1987. 
For a long-range program in sweet-potato breeding with the germplasm of its wild relatives, it is essential to study further the genomic relationship between sweet potato and its wild relatives.

In the present report, cytological studies were carried out on the two kinds of synthetic hexaploids. The first was the hexaploids derived from chromosome doubling of triploid hybrids between I. lacunosa (K 61, $2 n=30$ ) and I. tiliacea (K 134, $2 n=60$ ). The second synthetic hexaploids were derived from chromosome doubling of triploid hybrids between $2 x$ I. trifida (K 221, $2 n=30$ ) and $4 x$ I. trifida (K 233, $2 n=60)$.

There has been a long controversy between researchers in the taxonomic treatments of the wild Ipomoea plants. A brief account was given because it will help in understanding the species relationship to sweet potato better and in bringing together any information of each species.

\section{Materials and Methods}

The original Ipomoea strains used as the parent of the triploid hybrid and the first synthetic hexaploids are K 61, a diploid strain of I. lacunosa introduced from Baton Rouge, Louisiana in 1955 and K 231, a diploid strain of I.trichocarpa from Austin, Texas in 1959 and K 134, a tetraploid strain of I.tiliacea from Mexico in 1955. All of them were introduced by I. Nishryama. The other two original strains are the parent of the second synthetic hexaploids. $\mathrm{K} 221$ is a strain of $2 x$ I.trifida collected by M. Kobayashi in Acapulco, Guerrero, Mexico in 1960, and K 233 a strain of $4 x$ I. trifida collected by M. Muramatsu in Veracruz, Veracruz, Mexico in 1959.

Flowering of the parents and hybrids was induced by grafting their scions onto young plants of semi-dwarf morning glory (Kidachi-asagao, Pharbitis nil).

Cytological observations were made in root tip cells and PMC's. Root tips were pretreated in $0.002 \mathrm{~mol} 8$-hydroxyquinolin at $12^{\circ} \mathrm{C}$ for 3 hours. The root tips and buds were fixed in a $12: 5$ mixture of Newcomer's solution and acetic acid, and stored under refrigeration. Hydrolysis was done in a $12: 5: 2$ fresh mixture of Newcomer's solution, acetic acid and $3.6 \mathrm{~N}$ hydrochloric acid. The root tips were hydrolized at $40^{\circ} \mathrm{C}$ for 1 hour, and the buds at $42^{\circ} \mathrm{C}$ for 10 minutes, then the materials were stained with Schiff's reagent. Preparations were made by temporary iron-acetocarmine squash method.

All strains and hybrids are currently maintained as true seeds or clones in Kyushu Agricultural Experiment Station, Ibusuki, Kagoshima.

\section{Results}

1. Synthetic hexaploids with I.lacunosa (K 61) and I. tiliacea (K 134)

As shown in Fig. 1, the hexaploids were synthesized by colchicine treatment of sterile triploid hybrids between $\mathrm{K} 61(2 n=30)$ and $\mathrm{K} 134(2 n=60)$. A meiotic study was done on a plant (111) of the synthetic hexaploids. A total of 25 PMC's showed the number of bivalents ranged from 37 to 44 , a mean of 41.3. Multivalent associations were infrequent with a mean of 0.3 trivalents and 0.8 tetravalents per cell. Univalents, ranged from 0 to 6 , reduced the mean number of bivalent-equivalents to 43.2 . On 
the whole, the predominant bivalents suggested that diploidization took place or that three participating genomes were rather nonhomologous to each other (Table 1).

$\mathrm{K} 231$ is a strain of I.trichocarpa closely related to I.lacunosa. The two species were found to share the genome A by Jones and Deonier (1965), and it was confirmed by the normal behavior of meiosis, having 15 bivalents, in the $F_{1}$ hybrid between the two species (MarTiN 1970). Chromosome pairing in a sterile triploid hybrid (102) between $\mathrm{K} 231$ and K 134 showed a mean of 15.6 bivalents

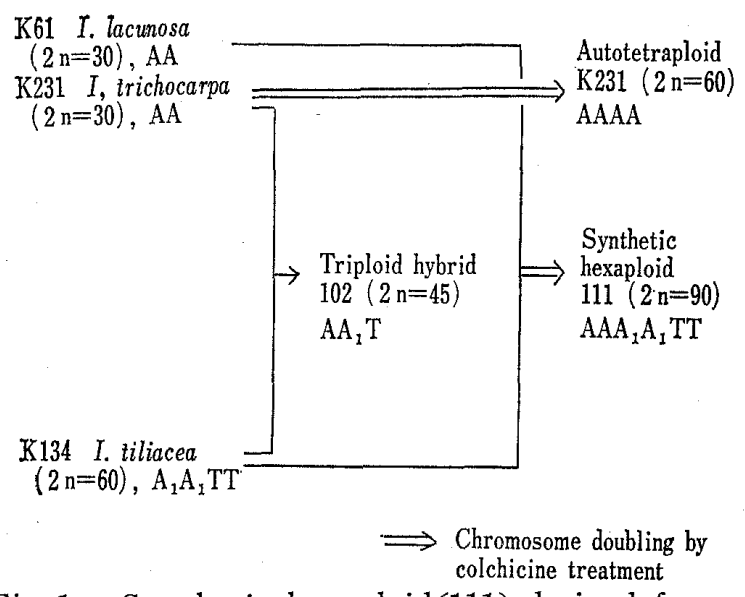

Fig. 1. Synthetic hexaploid(111) derived from I.lacunosa (K 61) and I.tiliacea (K 134), the triploid hybrid(102) between I. trichocarpa (K 231) and I. tiliacea (K 134), and an induced autotetraploid of $\mathrm{K} 231$.

with a range from 14 to 17 , and a mean of 13.7 univalents with a range from 11 to 17 in 11 PMC's examined. 18 PMC's of the autotetraploid of K 231 showed tetravalents ranged from 3 to 7 with a mean of 4.9 per cell, and 33.2 percent of the chromosomes were associated largely in tetravalents.

The present observations, and the meiotic data by Jones (1970) indicating that $I$. tiliacea is an allotetraploid species with nomal meiosis of about 30 bivalents, suggest the probable genomic constitution of the synthetic hexaploid and its parental strains as shown in Fig. 1.

2. Synthetic hexaploids with $2 x$ I.trifida (K 221) and $4 x$ I.trifida (K 233)

As indicated in Fig. 2, the hexaploids were synthesized by colchicine treatment of triploid hybrids from the crosses of $2 x$ I.trifida (K 221) $\times 4 x$ I.trifida (K 233). The meiosis of two synthetic hexaploids, plant no. 216 with $2 n=92$ somatic chromosomes and no. 220 with $2 n=90$, were examined. A total of 22 cells in 216 exhibited various amounts of chromosomes associations at MI as listed in Table 2. The mean number of the chromosomes participating in multivalents was 42.7 with a standard deviation of 9.28. Among the multivalents, tetravalents were the most frequent with a range

Table 1. Chromosome pairing at MI of the triploid hybrid (102) between I.trichocarpa (K 231) and I.tiliacea (K 134), an induced autotetraploid of $\mathrm{K} 231$, and the synthetic hexaploid (111).

\begin{tabular}{|c|c|c|c|c|c|c|c|c|}
\hline \multirow{2}{*}{$\begin{array}{c}\text { Strain } \\
\text { no. }\end{array}$} & \multirow{2}{*}{$2 n$} & \multirow{2}{*}{$\begin{array}{c}\text { No. of } \\
\text { cells }\end{array}$} & \multicolumn{6}{|c|}{ Mean number per cell of } \\
\hline & & & $\mathrm{I}$ & $\pi$ & III & $\mathbb{N}$ & II $-\mathrm{EQ}$ & CPM \\
\hline 102 & 45 & 11 & $\begin{array}{c}13.7 \\
(11 \sim 17)\end{array}$ & $\begin{array}{c}15.6 \\
(14 \sim 17)\end{array}$ & & & $\begin{array}{c}15.6 \\
(14 \sim 17)\end{array}$ & 0 \\
\hline $4 x \mathrm{~K} 231$ & 60 & 18 & $\begin{array}{c}0.1 \\
(0 \sim 1)\end{array}$ & $\begin{array}{c}20.0 \\
(16 \sim 24)\end{array}$ & $\begin{array}{c}0.1 \\
(0 \sim 1)\end{array}$ & $\begin{array}{c}4.9 \\
(3 \sim 7)\end{array}$ & $\begin{array}{c}29.9 \\
(29 \sim 30)\end{array}$ & $19.9 \pm 4.12$ \\
\hline 111 & 90 & 25 & $\begin{array}{c}3.2 \\
(0 \sim 6)\end{array}$ & $\begin{array}{c}41.3 \\
(37 \sim 44)\end{array}$ & $\begin{array}{c}0.3 \\
(0 \sim 3)\end{array}$ & $\begin{array}{c}0.8 \\
(0 \sim 2)\end{array}$ & $\begin{array}{c}43.2 \\
(42 \sim 45)\end{array}$ & $4.2 \pm 2.88$ \\
\hline
\end{tabular}

Roman numerals indicate number of associated chromosomes. II-EQ denotes bivalent-equivalents, and $\mathrm{CPM}$ chromosomes participating in multivalents. 
from 2 to 10 (mean 6.1). The second most frequent were hexavalents, with a range from 0 to 6 (mean 2.6). However, trivalents and pentavalents were infrequent with means of 1.2 and 0.3 respectively. The number of bivalent-equivalents with a range from 43 to 46 (mean 44.6) indicated almost complete chromosome pairing in the synthetic hexa ploid. The means of the univalents, bivalents, and multivalents in 8 cells of the plant no. 220 were similar to those of

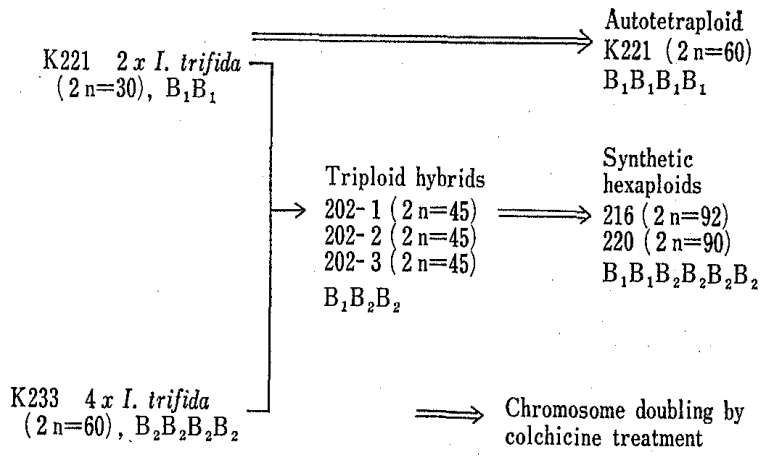

Fig. 2. Synthetic hexaploids (216 and 220) derived from $2 x$ I.trifida (K 221) and $4 x$ I.trifida (K 233), and an induced autotetraploid of $\mathrm{K} 221$.

216. And the mean number of the chromosomes participating in multivalents was 40.0 with a standard deviation of 8.16. Again, nearly complete chromosome pairing was implied by the mean number of bivalent-equivalents of 43.8.

Chromosome pairing in both of the hexaploids was characterized by the frequent occurrence of tetravalents and hexavalents. Such multivalents were traced back to

Table 2. Chromosome pairing at MI of the triploid hybrids (202), their parent $\mathrm{K} 221$ and $\mathrm{K} 233$, the synthetic hexaploids (216 and 220), an induced autotetraploid of $\mathrm{K} 221$, an $\mathrm{F}_{1}$ hybrid ( $\mathrm{K} 6843$ ) of $216 \times \mathrm{Kanto} 48$, and a sweet potato cultivar Kyushu 58.

\begin{tabular}{|c|c|c|c|c|c|c|c|c|c|c|}
\hline \multirow{2}{*}{$\begin{array}{l}\text { Strain } \\
\text { no. }\end{array}$} & \multirow{2}{*}{$2 \mathrm{n}$} & \multirow{2}{*}{$\begin{array}{l}\text { No. of } \\
\text { cells }\end{array}$} & \multicolumn{8}{|c|}{ Mean number per cell of } \\
\hline & & & $\mathrm{I}$ & III & IIII & $\mathbb{N}$ & $\mathrm{V}$ & $\mathrm{VI}$ & II $-\mathrm{EQ}$ & $\mathrm{CPM}$ \\
\hline $\mathrm{K} 221$ & 30 & 16 & & 15 & & & & & 15 & 0 \\
\hline $5 x \mathrm{~K} 221$ & 60 & 30 & $\begin{array}{c}0.9 \\
(1 \sim 5)\end{array}$ & $\begin{array}{c}18.1 \\
(13 \sim 22)\end{array}$ & $\begin{array}{l}0.2 \\
(0 \sim 1)\end{array}$ & $\begin{array}{c}5.6 \\
(4 \sim 8)\end{array}$ & & & $\begin{array}{c}29.8 \\
(27 \sim 30)\end{array}$ & $23.0 \pm 4.58$ \\
\hline $\mathrm{K} 233-1$ & 60 & 9 & & $\begin{array}{c}21.8 \\
(18 \sim 24)\end{array}$ & & $\begin{array}{c}4.1 \\
(3 \sim 6)\end{array}$ & & & 30.0 & 16. $4 \pm 3.71$ \\
\hline $\mathrm{K} 233-1$ & 60 & 28 & $\begin{array}{c}0.04 \\
(0 \sim 1)\end{array}$ & $\begin{array}{c}20.4 \\
(16 \sim 26)\end{array}$ & $\begin{array}{c}0.04 \\
(0 \sim 1)\end{array}$ & $\begin{array}{c}4.8 \\
(2 \sim 7)\end{array}$ & & & $\begin{array}{c}30.0 \\
(29 \sim 30)\end{array}$ & 19. $3 \pm 5.34$ \\
\hline $202-1$ & 45 & 21 & $\begin{array}{l}9.9 \\
(6 \sim 15)\end{array}$ & $\begin{array}{c}13.0 \\
(8 \sim 16)\end{array}$ & $\begin{array}{c}3.0 \\
(2 \sim 5)\end{array}$ & & & & $\begin{array}{c}16.0 \\
(13 \sim 18)\end{array}$ & $9.0 \pm 3.29$ \\
\hline $202-2$ & 45 & 9 & $\begin{array}{c}9.0 \\
(5 \sim 13)\end{array}$ & $\begin{array}{c}13.2 \\
(10 \sim 17)\end{array}$ & $\begin{array}{c}2.9 \\
(2 \sim 4)\end{array}$ & $\begin{array}{c}0.1 \\
(0 \sim 1)\end{array}$ & & & $\begin{array}{c}16.3 \\
(14 \sim 18)\end{array}$ & $9.1 \pm 2.76$ \\
\hline $202-3$ & 45 & 10 & $\begin{array}{l}8.9 \\
(6 \sim 12)\end{array}$ & $\begin{array}{c}14.3 \\
(12 \sim 18)\end{array}$ & $\begin{array}{c}2.5 \\
(1 \sim 4)\end{array}$ & & & & $\begin{array}{c}16.8 \\
(15 \sim 19)\end{array}$ & $7.5 \pm 3.24$ \\
\hline 216 & 92 & 22 & $\begin{array}{c}1.2 \\
(0 \sim 3)\end{array}$ & $\begin{array}{c}22.6 \\
(11 \sim 30)\end{array}$ & $\begin{array}{l}1.2 \\
(0 \sim 4)\end{array}$ & $\begin{array}{c}6.1 \\
(2 \sim 10)\end{array}$ & $\begin{array}{c}0.3 \\
(0 \sim 2)\end{array}$ & $\begin{array}{c}2.6 \\
(0 \sim 6)\end{array}$ & $\begin{array}{c}44.6 \\
(43 \sim 46)\end{array}$ & $42.7 \pm 9.28$ \\
\hline 220 & 90 & 8 & $\begin{array}{c}0.8 \\
(1 \sim 3)\end{array}$ & $\begin{array}{c}24.6 \\
(17 \sim 31)\end{array}$ & $\begin{array}{l}1.4 \\
(1 \sim 4)\end{array}$ & $\begin{array}{c}4.8 \\
(2 \sim 7)\end{array}$ & $\begin{array}{c}0.4 \\
(0 \sim 1)\end{array}$ & $\begin{array}{c}2.5 \\
(1 \sim 5)\end{array}$ & $\begin{array}{c}43.8 \\
(43 \sim 45)\end{array}$ & $40.0 \pm 8.16$ \\
\hline K 6843 & 93 & 30 & $\begin{array}{l}2.0 \\
(0 \sim 5)\end{array}$ & $\begin{array}{c}24.1 \\
(16 \sim 32)\end{array}$ & $\begin{array}{c}0.4 \\
(0 \sim 3)\end{array}$ & $\begin{array}{c}5.3 \\
(2 \sim 9)\end{array}$ & & $\begin{array}{c}3.4 \\
(1 \sim 6)\end{array}$ & $\begin{array}{c}45.3 \\
(44 \sim 46)\end{array}$ & $42.7 \pm 8.13$ \\
\hline Kyushu 58 & 94 & 20 & $\begin{array}{c}1.3 \\
(0 \sim 6)\end{array}$ & $\begin{array}{c}26.8 \\
(22 \sim 34)\end{array}$ & $\begin{array}{c}0.9 \\
(0 \sim 4)\end{array}$ & $\begin{array}{c}5.7 \\
(2 \sim 7)\end{array}$ & $\begin{array}{c}0.1 \\
(0 \sim 1)\end{array}$ & $\begin{array}{c}2.2 \\
(1 \sim 4)\end{array}$ & $\begin{array}{c}45.9 \\
(43 \sim 47)\end{array}$ & $39.1 \pm 5.96$ \\
\hline
\end{tabular}

Kanto 48 is a selected line from the single crosses with 4 native sweet potato varieties. Kyushu 58 is a selected line from the cross of (L-4-5×K 123) $\times$ Kanto 48 . 
bivalent and trivalent associations in the triploid hybrids between K 221 and K 233 . Three triploid hybrids showed, as expected, the means of 13. $0,13.2$ and 14.3 bivalents, and the means of $3.0,2.9$ and 2.5 trivalents. Consequently, the means of bivalentequivalents were $16.0,16.3$ and 16.8 respectively.

Sixteen cells of the diploid parent K 221 showed normal metaphase with 15 bivalents. Two clonal strains of the tetraploid parent K 233 exhibited a similar chromosome pairing to each other, and the meiotic data showed the frequent occurrence of tetravalents up to a mean of 4.1 and 4.8 respectively. They showed almost complete chromosome pairing with a mean of bivalent-equivalents of 30.0. Thirty cells of a plant of autotetraploid K 221 showed a mean of 5.6 tetravalents and 29.8 bivalent-equivalents.

The present observation of chromosome pairing in K 233 confirmed the contention that the plant belonging to K 233 taxon is an autotetraploid by JonEs (1970). Therefore, approximately 15 bivalents of the triploid hybrids are ascribed to autosyndetic pairing between the two genomes from K233. Further, trivalents involving 7.5 9.1 chromosomes per cell showed that the genome from K 221 had some degree of homology to the other genome in duplicate.

All configurations at $\mathrm{MI}$ in the $\mathrm{F}_{1}$ hybrid (K 6843, 2 n=93) from the cross between sweet potato cultivar (Kanto 48) and the synthetic hexaploid (216, $2 n=92$ ) are shown in Table 2. Univalents (mean 2.0) and trivalents (mean 0.4) were occasional and no pentavalent was observed. Tetravalents ranging from 2 to 9 (mean 5.3) and hexavalents ranging from 1 to 6 (mean 3.4) were observed in 30 cells analyzed. The overall number of chromosome pairing represented by the number of bivalent-equivalents ranged from 44 to 46 , a mean of 45.3 . Of 93 chromosomes 42.7 per cell were participating in multivalents, largely in tetravalents and hexavalents.

Table 2 includes chromosome pairing of a cultivar of sweet potato, Kyushu 58 ( $2 n=$ 94). Kyushu 58 is a selected line from the cross of ( $-4-5 \times \mathrm{K} 123) \times$ Kanto 48 . It showed a wide range of chromosome associations from bivalent to hexavalent in 20 cells examined. Of 94 chromosomes 39.1 per cell were participating in multivalents. Although the mean of hexavalents of 2.2 was less than that of the hybrid (K 6843), there were no marked differences from those of the synthetic hexaploids. As a result, the $F_{1}$ hybrid of sweet potato $\times$ synthetic hexaploid indicated an essentially similar pattern of chromosome pairing to those of the sweet potato and the synthetic hexaploid. As will be discussed later, these findings provide the possibility that the hexaploids derived from K 221 and K 233 have an equal genomic constitution to that of sweet potato.

\section{Discussion}

A synthetic hexaploid derived from triploid hybrids of I.lacunosa (K 61) and $I$. tiliacea (K 134) achieved almost normal meiosis having a mean of 43 bivalents and infrequent multivalents. Therefore, the synthetic hexaploid was thought to be alloor segmental allohexaploid.

The frequent bivalents with a range from 14 to 17 (mean 15.6) of the triploid hybrid of $\mathrm{K} 231 \times \mathrm{K} 134$ seem to suggest that I. tiliacea $\mathrm{K} 134$ has a genome homologous 
to A genome from K 231. However, the synthetic hexaploid did not from so frequent tetravalents as the autotetraploid K 231 .

Consequently, I. tiliacea K 134 was assumed to have one modified genome $\mathrm{A}_{1}$ and the other genome labelled $T$. As a result, the genomic constitution for the synthetic hexaploid is tentatively designated $A_{1} T$. The genome $A$ and $A_{1}$ are supposed to take place preferential pairing and it may cause the predominant bivalent formation in the synthetic hexaploid. Further study is necessary for genomic differentiation between A genomes in diploid I. lacunosa and I.trichocarpa and $\mathrm{A}_{1}$ genomes in the tetraploid I. tiliacea. As shown in Table 1, diploidization in the first synthetic hexaploid was characteristic in contrast to chromosome pairing in another synthetic hexaploids and sweet potato.

In the present report, data of crossability was cited from the crossing experiments conducted as a part of sweet-potato breeding in Kyushu Agricultural Experiment Station, Ibusuki, Kagoshima. As no hybrids were obrained in crosses between I.lacunosa (K 61) and sweet potato nor in crosses between I. tiliacea (K 134) and sweet potato (K. A. E. S. 1963), an attempt to cross the synthetic hexaploids with sweet potato was of major interest. The hexaploid (111) and other individual plants were quite fertile, showing 48.6 percent of seed set in cross-pollination and 3.4 percent in self-pollination. Fifteen crosses with 750 flowers of sweet potato pollinated with the synthetic hexaploid pollen yielded no seeds, while 15 reciprocal crosses with 750 flowers produced 15 seeds. Of them 4 seeds germinated and all were matroclinous progenies (K. A.E.S. 1963). From the results of crossing, it is suggested that the synthetic hexaploids and their parent I. lacunosa and I.tiliacea are isolated by a reproductive barrier from sweet potato. Although plants of I.lacunosa and I. tiliacea are similar in morphology to sweet potato, they are wild gene pools that require a considerable amount of effort to utilize them in sweet potato breeding.

Earlier studies by Ting and Kehr (1953), Ting et al. (1957) and Jones (1965) on meiotic behavior of sweet potato illustrated highly regular metaphase with the occurrence of bivalents and rare multivalents. On the other hand, from the karyological identification of the pachytene chromosomes and the multivalent analysis at pachytene and metaphase I, MAGoon et al. (1970) indicated that the three parental genomes are partly homologous and that two of the three genomes show closer homology to one another than to the third.

In the present observations, similar multivalent associations were seen in the secondsynthetic hexaploids, sweet potato, and a $F_{1}$ hybrid between the synthetic hexaploid and sweet potato. The second synthetic hexaploids were derived from chromosome doubling of triploid hybrids between $2 x$ I.trifida (K 221) and $4 x$ I.trifida (K 233). By labelling the genome of $\mathrm{K} 221$ as $\mathrm{B}_{1}$ and $\mathrm{K} 233$ as $\mathrm{B}_{2}$, the genomic constitution of the synthetic hexaploid is written as $\mathrm{B}_{1} \mathrm{~B}_{2} \mathrm{~B}_{2}$. Chromosome pairing of the synthetic hexaploids was characterized by frequent tetravalents formed by four genomes of $\mathrm{K} 233$ and hexavalents formed by two $B_{1}$ genomes of $K 221$ and four $B_{2}$ genomes of $K 233$. The degree of homology between $\mathrm{B}_{1}$ and $\mathrm{B}_{2}$ can not be estimated accurately at the level of hexaploidy. However, some degree of homology is suspected by the occurrence 
of trivalents in the triploid hybrids.

The $F_{1}$ hybrid (K 6843, $2 n=93$ ) between sweet potato (Kanto 48, $2 n=c .90$ ) and the synthetic hexaploid (216, $2 n=92)$ represented the similar meiotic configurations of chromosomes with predominant tetravalents and hexavalents to those of sweet potato and the synthetic hexaploids. If one assumes that a genome in duplicate is nonhomologous to a genome in quadruplicate in either of the hexaploid parent, sweet potato and the synthetic hexaploid, it will simplify the model for genomic constitution of their $F_{1}$ hybrid. Based on the above assumption, $B_{1}$ should be non-homologous to $B_{2}$ in the synthetic hexaploid. On the other hand, seven possible genomic constitution for the sweet-potato parent can be formulated, depending on the common genome and the degree of its duplication, as follows: $\mathrm{B}_{3} \mathrm{~B}_{4} \mathrm{~B}_{4}$ in the case when there is no common genomes; $\mathrm{B}_{1} \mathrm{~B}_{3} \mathrm{~B}_{3}, \quad \mathrm{~B}_{1} \mathrm{~B}_{1} \mathrm{~B}_{3}, \quad \mathrm{~B}_{2} \mathrm{~B}_{3} \mathrm{~B}_{3}$, or $\mathrm{B}_{2} \mathrm{~B}_{2} \mathrm{~B}_{3}$ when $\mathrm{B}_{1}$ or $\mathrm{B}_{2}$ genome in common; $\mathrm{B}_{1} \mathrm{~B}_{2} \mathrm{~B}_{2}$ or $B_{1} B_{1} B_{2}$ when both $B_{1}$ and $B_{2}$ genomes in common. When there is no common genome involved, for example, the $\mathrm{F}_{1}$ hybrid having $\mathrm{B}_{1} \mathrm{~B}_{2} \mathrm{~B}_{2} \mathrm{~B}_{3} \mathrm{~B}_{4} \mathrm{~B}_{4}$ will display a meiotic pattern with 30 bivalents and 30 univalents. Only in the case when the sweet-potato parent has the same genomes as $B_{1} B_{2} B_{2}$, the $F_{1}$ is expected to show 15 bivalents by $B_{1} B_{1}$ and 30 bivalent-equivalents by $B_{2} B_{2} B_{2} B_{2}$ and to form reasonably frequent tetravalents.

Next, if one assumes a genome in duplicate is completely homologous to a genome in quadruplicate, it is a condition of autohexaploidy for both of the parent. When the parent are made up of different genome, the $F_{1}$ hybrid shows chromosome pairing typical of autotriploidy for the respective genomes. When they are autohexaploids with respect to an identical genome, meiosis of $F_{1}$ is expected to show chromosome pairing with 45 bivalent-equivalents involving multivalents such as tetra- and hexavalents. As mentioned already, a possibility of autohexaploid structure of sweet potato as well as the synthetic hexaploid is not rejected until the chromosomal homology between $\mathrm{B}_{1}$ and $\mathrm{B}_{2}$ is analyzed at the lower ploidy level.

The fertility of the synthetic hexaploids and their hybrids is one important indicator of the functional genomic homology, for it may be a measure of the ability of the parent to exchange genes. As the synthetic hexaploids were self-incompatible, intercrosses were made between the plants in $\mathrm{C}_{2}$ generation. Such 12 intercrosses showed 11.0 percent in seed set. In hybridization with sweet potato, 1,250 flowers yielded as low as 2.6 percent of seed set in 18 crosses with sweet potato as female parent, and 1,000 flowers an appreciable seed set of 10.2 percent in 20 crosses with sweet potato as male parent (K.A.E.S. 1969 1970). A series of the crossing data indicates that fertility of the synthetic hexaploids is partially retained and they are able to produce hybrids with sweet potato.

Regarding the fertility of $F_{1}$ hybrids of the synthetic hexaploids $\times$ sweet potato, 4,122 flowers of the $F_{1}$ hybrids in 12 back-crosses with sweet potato provided 27.4 percent of seed set (K. A.E.S. 1971 1972). The percentage in seed fertility indicates the $F_{1}$ hybrids are as fertile as sweet potato. The above crossing data involving the synthetic hexaploids are compatible with the cytological findings that the synthetic hexaploids are principally identical in genomic constitution to sweet potato.

There has been a long controversy in taxonomic treatments of the Ipomoea strains 
Table 3. Identification of the parental Ipomoea strains

\begin{tabular}{|c|c|c|c|c|c|c|c|}
\hline $\begin{array}{l}\text { Parental } \\
\text { strain }\end{array}$ & Ploidy & $\begin{array}{c}\text { NISHIYAMA } \\
\text { and } \\
\text { TERAMURA } \\
(1962)\end{array}$ & $\begin{array}{l}\text { TERAMURA } \\
\text { et al. (1967) }\end{array}$ & $\begin{array}{l}\text { NISHIYAMA } \\
(1971)\end{array}$ & $\begin{array}{l}\text { AUSTIN } \\
(1978)\end{array}$ & $\begin{array}{l}\text { SHIOTANI } \\
\text { and } \\
\text { KAWASE } \\
(1980)\end{array}$ & $\begin{array}{l}\text { AUSTIN } \\
\text { (1983) }\end{array}$ \\
\hline \multicolumn{8}{|c|}{ Parent of the first synthetic hexaploids and the other } \\
\hline K61 & $2 x$ & I. triloba L. & $\begin{array}{l}\text { I. lacunosa } \\
\text { L. }\end{array}$ & $\begin{array}{l}\text { I. triloba } \\
\text { var. triloba } \\
\text { f. lacunosa } \\
\text { NisH. }\end{array}$ & & $\begin{array}{l}\text { I. lacunosa } \\
\text { L. }\end{array}$ & - \\
\hline $\mathrm{K} 231$ & $2 x$ & - & $\begin{array}{l}\text { I. lacunosa } \\
\text { L. }\end{array}$ & - & & $\begin{array}{l}\text { I. trichocarpa } \\
\text { ELL. }\end{array}$ & - \\
\hline K134 & $4 x$ & $\begin{array}{l}\text { I. gracilis } \\
\text { R. BR. }\end{array}$ & $\begin{array}{l}\text { I.gracilis } \\
\text { R. BR. }\end{array}$ & $\begin{array}{l}\text { I. gracilis } \\
\text { R. BR. }\end{array}$ & & $\begin{array}{l}\text { I.tiliacea } \\
\text { CHOISY }\end{array}$ & $\begin{array}{l}\text { Feral sweet } \\
\text { potato }\end{array}$ \\
\hline \multicolumn{8}{|c|}{ Parent of the second synthetic hexaploids } \\
\hline $\mathrm{K} 221$. & $2 x$ & - & $\begin{array}{l}\text { I. leucantha } \\
\text { JACQ. }\end{array}$ & $\begin{array}{l}\text { I. batatas } \\
\text { var. leuc- } \\
\text { antha NISH. }\end{array}$ & $\begin{array}{l}\text { I. } \times \text { leucan- } \\
\text { tha } \\
\text { JACQ. }\end{array}$ & $\begin{array}{l}2 x \text { I. trifida } \\
\text { (H. B. K.) } \\
\text { G. DoN. }\end{array}$ & $\begin{array}{l}\text { I. trifida } \\
\text { (H. B. K.) } \\
\text { G. DoN. }\end{array}$ \\
\hline K233 & $4 x$ & - & $\begin{array}{l}\text { I. littoralis } \\
\mathrm{BL}_{\mathrm{L}}\end{array}$ & $\begin{array}{l}\text { I. batatas } \\
\text { var. litto- } \\
\text { ralis NISH. }\end{array}$ & $\begin{array}{l}\text { I. littoralis } \\
\text { BL. }\end{array}$ & $\begin{array}{l}4 x \text { I. trifida } \\
\text { (H. B. K.) } \\
\text { G. DoN. }\end{array}$ & $\begin{array}{l}\text { Feral sweet } \\
\text { potato }\end{array}$ \\
\hline
\end{tabular}

as listed in Table 3. Species name used in the present study were those based on the identification by SHIotani and KAwAse (1980). K 231 was considered to be a strain of I.trichocarpa according to the analysis in numerical taxonomy of Ipomoea diploid strains (Shiotani and Kawase 1970). A tetraploid strain K 134 from Mexico was first treated as I. gracilis by Nishiyama and Teramura (1962), but the authors identified K 134 with a tetraploid strain (K 270) of I. tiliacea from Puerto Rico. Recently, Austin (1983) examined K 134 and treated it as a feral sweet potato.

The first tentative identification of K221 and K 233 was based on the descriptions of Choisy's monograph in 1845 (Teramura et al. 1967). Nishiyama (1971) proposed a new taxonomy of sweet potato and its related taxa with using ranks of variety and form. Austin's taxonomic work was expected to clear up most of the areas of uncertain identification, but from the publication on Ipomoea batatas complex (Austin 1978), it does not appear to have done so. According to his treatments, K 221 was thought to be a natural hybrid I. Xleucantha between I.lacunosa and I.trichocarpa. However, later Austin (1983) examined the plant material of K 221 and identified it as I. trifida, and in addition he identified K 233 as a feral sweet potato.

Many wild Ipomoea plants, collected in Mexico and Guatemala, contained the diploids of K 221 type and tetraploids of K 233 type (Muramatsu and Shiotani 1974). Measurements of floral organs in these plants were outside of the variation given by Choisy's description of either I. leucantha or I.littoralis, but they fell within the range of organ size in descriptions of I. trifida (H. B. K.) G. Don. by O'Donell (1961) and Austin (1978).

\section{Acknowledgements}

The plant materials were prepared by the courtesy of the Second Crop-laboratory, Kyushu Agricultural Experiment Station, Ibusuki, Kagoshima, to which we are most thankful. We also wish to thank Dr. T. Teramura, Kyoto University, for his kind advice and encouragement. 


\section{Literature Cited}

Austin, D. F. 1978. The Ipomoea batatas complex-I. Taxonomy. Bull. Torrey Bot. Club 105 : $114 \sim 129$.

1983. Variability in sweet potatoes in America. Proc. Amer. Soc. Hort. Sci., Trop. Region 27(B) : 15 26.

JoNES, A. 1965. Cytological observations and fertility measurements of sweet potato (Ipomoea batatas (L.) LAM.). Proc. Amer. Soc. Hort. Sci, $86: 527 \sim 537$.

- - and M.I. DEONIER 1965. Interspecific crosses among Ipomoea lacunosa, I.ramoni, I.trichocarpa and I. triloba. Bot. Gaz. 126 : 226 232.

1970. Asynapsis in Ipomoea gracilis. J. Hered. 61: 151 152.

KoBAYASHI, M. 1978. Sweet potato breeding method using wild relatives in Japan. Trop. Agr. Res. Series $11: 1 \sim 8$.

K. A.E.S. (Kyushu Agr. Exp. Sta., Ibusuki, Kagoshima) 1963. Crossing experiments in sweet potato. Ann. Report : $1 \sim 124$. (in Japanese)

1969 1970. Crossing experiments in sweet potato. Ann. Report: $1 \sim 154$. (in Japanese)

1971 1972. Crossing experiments in sweet potato. Ann. Report: 1 98, (in Japanese)

MAgoon, M. L., R. KRISHNAN and K. VIJAYA BAI 1970. Cytological evidence on the origin of sweet potato. Theor. Appl. Genet. $40: 360 \sim 366$.

Martin, F. W. 1970. Sterility in some species related to the sweet potato. Euphytica $19: 459 \sim 464$.

-, A. JONES and R. M. RUBERTÉ 1974. A wild Ipomoea closely related to the sweet potato. Econ. Bot. $28: 287 \sim 292$.

Muramatsu, M. and I. ShIOTANi 1974. Closely related wild Ipomoea species of the sweet potato in Mexico and Guatemala. Report Plant Germ-plasm Inst. Fac. Agr. Kyoto Univ. 1:9 13, $19 \sim 30$.

NishiyAma, I. and T. Teramura 1962. Mexican wild form of sweet potato. Econ. Bot. $16: 304 \sim 314$. 1963. The origin of the sweet potato. 10 th Pacific Sci. Cong. Honolulu, In J.BARRAU (Ed.) Sym. "Plants and the migrations of Pacific people" $1963: 119 \sim 128$.

1971. Evolution and domestication of the sweet potato. Bot. Mg. Tokyo 84:377 387.

O’DONELl, C. A. 1960. Notas sobre Convolvulaceas americanas. Lilloa $30: 39 \sim 69$.

ShIOTANI, I., T.KAWASE 1970. Principle component analysis of the Ipomoea diploid species and hybrids. Japan J. Breed. 20 Suppl. $2:$ 18 19. (in Japanese)

- 1980 . Origin and differentiation of the sweet potato. Genome constitution and domestication. Japan J. Breed. 30 Suppl. $2: 306 \sim 309$. (in Japanese)

TERAmura, T., I. ShIotAnI and T. KAWASE 1967. Triploid plants of Ipomoea collected in Mexico. Japan J. Breed. 17 Suppl. $2: 187 \sim 188$. (in Japanese)

TING, Y.C. and A.E. KEHR 1953. Meiotic studies in the sweet potato (Ipomoea batatas LAM.). J. Hered. $44: 207 \sim 211$.

- - and J. C. MILLER 1957. A cytological study of the sweet-potato plant (Ipomoea batatas (L.) LAM.) and its related species. Amer. Nat. 91: 197 203. 
サッマイモ近縁野生種から作出した合成 6 倍体

\author{
塩谷 格・川瀬 恒男 \\ (三重大学農学部, 津市, 干 514)
}

サッマイモ育種では，生殖質の多様化をはかる方法の一環として，近縁野生種の育種的利用を進めてきた。 その成果として，線虫抵抗性をるつ高でん粉多収性の系統・品種育成をみるにいたった。サッマイモは 6 倍体 (2n=90) で, 一方, その近縁野生種には 2 倍体, 4 倍体, 6 倍体功ある. これら野生種怙よびサッマイモの倍数 性に関与しているゲノムについてはいまだ十分解明されていない，本報告では，野生種をむちいてできた2種 類の合成 6 倍体, それらの両親, 括よびサッマイモとの交雑から生じた $F_{1}$ 雑種について, 隇数分裂第 1 分裂中 期の染色体対合を観察し，それら植物のゲノム構成を明らかたしようとした.

第 1 の合成 6 倍体は Ipomoea lacunosa (K61,2n=30) と I. tiliacea (K 134, $2 n=60)$ との 3 倍体雑種の 染色体倍加によってえられた（Fig. 1).この6 倍体で恃，低頻度の 1 価，3 価，4価染色体がみられたが，平 均 41.3 の 2 価染色体がみられた. そして平均 $43.2 の 2$ 価染色体相当数があり, 全体として異質または部分異質 6 倍体の染色体対合とみなすことができた（Table 1)． 3 倍体雑種としては I. trichocarpa (K 231，2n=30) とK 134 との雑種が供試された. I. lacunssa と I. trichocarpa は共通のゲノムAをもつことが明らがなっ ている. また Jones (1970) によれば，I. tiliacea は異質 4 倍体としての染色体対合を示している. 以上のこ とから，I.tiliacea のゲノム構成を $\mathrm{A}_{1} \mathrm{~A}_{1} \mathrm{TT}$ として，合成 6 倍体に暫定的なゲノム式 $\mathrm{AAA}_{1} \mathrm{~A}_{1} \mathrm{TT}$ を与えた. この合成 6 倍体は高い稔性をるつが，サッマイモとの交雑からは雑種を得ることはできなかった (K. A.E.S. 1963).

第 2 の合成 6 倍体は，2x I.trifida (K 221，2n=30) と $4 x$ I. trifida (K 233，2n=60）との 3 倍体雑種 の染色体倍加によるものである (Fig. 2). 4 倍体親の K 233 は 4 価染色体の出現頻度から同質 4 倍体と判定さ れた (Table 2). したがって，上記の 3 倍体雑種がみせる 1 対のゲノム対合に相当する 2 価染色体は，K 233 由 来の 2 つのゲノムの同親対合によると推定された.

Table 2 飞示すように, 合成 6 倍体は，3 倍体雑種の対合型から期待されたと招りに，4 価染色体（平均 4.8 と 6. 1)，また 6 価染色体（平均 2.5 と 2.6）を示した. 2 倍体親 $\mathrm{K} 221$ からのゲノムを $\mathrm{B}_{1}, 4$ 倍体親 $\mathrm{K} 233$ からのゲノムを $\mathrm{B}_{2} \mathrm{~B}_{2}$ として，合成 6 倍体に $\mathrm{B}_{1} \mathrm{~B}_{1} \mathrm{~B}_{2} \mathrm{~B}_{2} \mathrm{~B}_{2} \mathrm{~B}_{2}$ のゲノム式を与克た。ただし， $\mathrm{B}_{1} \cdot \mathrm{B}_{2}$ ゲノム 間にはかなりの相同性があると推察されるが，その程度については今後の研究が必要である。

第 2 の合成 6 倍体とサッマイモ（関東 48 号）との $\mathrm{F}_{1}$ 雑種の染色体対合は合成 6 倍体のそれと大差はなかっ た. 季た，サツマイモ（九州 58 号）す 4 価や 6 洒染色体を形成し, 合成 6 倍体と同様な対合型を示した.

合成 6 倍体で 4 重になっている $\mathrm{B}_{2}$ ゲノムとサッマイモで 4 重になっているゲノムが相同な場合，㐫るいは非 相同な場合, さらに 2 重になっているゲノムについてる, 両者間で相同あるいは非相同な場合を想定したとき，

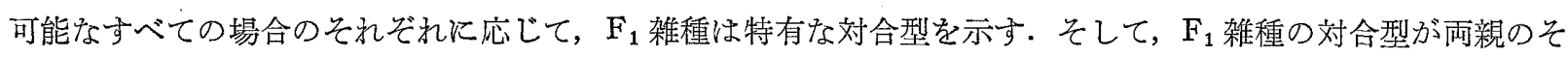

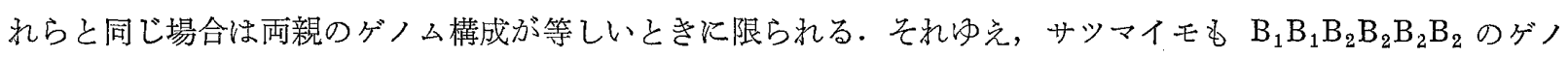
ム構成をもつと考觉られる。

この結論は第 2 の合成 6 倍体の 関与した交雑試験からも支持された。この合成 6 倍体はサッマイモと交雑可 能であり, それらの $\mathrm{F}_{1}$ 雑種も委を稔性をるつ. その稔実率は， $\mathrm{F}_{1}$ 雑種のサッマイモへの戻し交雑では，サッ マイモ系統・品種間の平均的な秎実率程度の値を示した (K. A. E.S. 1971〜1972).

本報告に供試した野生種系統の 分類学上の同定については，見解を異にするいくつかの提案がなされてきた が，それらの諸観点を要約した (Table 3). 